\title{
Hepatic and branchial biomarker responses in Solea spp. from several NW
}

\section{Mediterranean fishing grounds}

\author{
R. Siscar ${ }^{1}$, I. Varó $^{2}$ and M. Solé ${ }^{3 *}$
}

${ }^{1}$ Departamento Biología Funcional y Antropología Física. Universitat de València. Dr. Moliner 50 Burjassot 46100 Valencia, Spain

${ }^{2}$ Instituto de Acuicultura Torre de la Sal (IATS-CSIC), 12595 Ribera de Cabanes, Castellón, Spain.

${ }^{3}$ Institut de Ciencies del Mar (ICM-CSIC). Passeig marítim de la Barceloneta 37-49 08003 Barcelona, Spain.

* Corresponding author. Tel.: +34 9323095 00; fax: +34 932309555 .

E-mail address: $\underline{\text { msole@icm.csic.es }}$ 


\begin{abstract}
The common sole, Solea solea and the Senegalese sole, Solea senegalensis are two important commercial benthic species that coexist in the NW Mediterranean Sea. Several common biomarkers of chemical exposure were measured in two organs (liver and gills) involved in a different degree in biotransformation and detoxification processes. These parameters were: phase I cytochrome P450 CYP1A-dependent ethoxyresorufin $O$-deethylase and carboxylesterase activities, phase II glutathione $S$ transferase activity and the antioxidant defence mechanisms: catalase, glutathione reductase and glutathione peroxidase. Principal Component Analysis (PCA) considering all liver and gill biomarkers discriminated individuals collected at the different fishing grounds, more clearly in $S$. senegalensis, as individuals were from two more distant geographical sites. Esterase inhibition by the organophosphate pesticides dichlorvos and diazinon was also compared in vitro in muscle, liver and gill of the two species. The use of benthic sole in pollution monitoring of Southern Europe is discussed as alternative sentinel to other benthic fish from more Northern latitudes.
\end{abstract}

Keywords: EROD, GST, CbE, antioxidant enzymes, dichlorvos, diazinon. 


\section{Introduction}

Benthic fish, and particularly Solea species (Solea solea and Solea senegalensis), are important economic resources that coexist in the Mediterranean region and are highly appreciated for human consumption (Imsland et al., 2003). Thus, presence of significant levels of toxic chemicals in these species can not only affect their physiological performance but also negatively affect consumer's health. A few studies in the Mediterranean have already reported on the presence of pesticides, metals and persistent organic pollutants in these two fish species (Ben Ameur et al., 2013; Dierking et al., 2009; Trisciani et al., 2011; Sanchez-Nogué et al., 2012; Siscar et al., 2013). In particular, the use of $S$. senegalensis as sentinel species, amply exceeds that of S. solea and it corresponds mostly to studies conducted in Atlantic waters (Costa et al., 2009; 2010; 2012; Fonseca et al., 2011a; 2011b; Oliva et al., 2010; 2012; Gonçalves et al., 2013; 2014). By contrast, the use of $S$. solea as sentinel species in Southern Europe is more restricted (Trisciani et al., 2011; Ribeco et al., 2012; Jebali et al., 2013; Siscar et al., 2013). In addition, most of these field studies have focussed on juvenile specimens of S. senegalensis from estuarine areas, as little mobility habits have been demonstrated in this age group (Vinagre et al., 2013). However, studies with adults of S. solea have also validated their adequacy as sentinels. Tissue chemical analysis of adult fish could discriminate populations, suggesting little mobility habits also during adulthood; in spite of the annual reproductive migrations to more coastal waters (Dierking et al., 2009). From recent laboratory exposures, there is also growing evidence that Solea spp. are responsive to pollutants (Costa et al., 2009; López-Galindo et al., 2010a; b; Wessel et al., 2010; Solé et al., 2014). All these field and laboratory studies point out that $S$. senegalensis and S. solea could serve as good alternative sentinels to other flatfish species (e.g. Platichthys flesus, Parophrys, Pleuronectes vetulus, Scophthalmus 
maximus and Limanda limanda) broadly used in Northern latitudes (Akcha et al., 2003; Kopecka and Pempkowiak, 2008; Lehtonen et al., 2006; Lerebours et al., 2014; Napierska and Podolska, 2005).

Biomarkers of chemical exposure such as cytochrome P450 CYP1A1-related ethoxyresorufin O-deethylase (EROD) activity, carboxylesterase (CbE), conjugation glutathione S-transferase (GST) and the antioxidant defences catalase (CAT), glutathione reductase (GR) and glutathione peroxidase (GPX) are of widespread use in pollution monitoring studies (Van der Oost et al., 2003). Responses to pollutants can be measured in liver, as the main biotransformation organ, but also in gill as the first target tissue for water borne chemicals and site for presystemic metabolism (Barron et al., 1999; Regoli et al 2011). The approach, using both tissues, has been applied in laboratory exposures with S. senegalensis (López-Galindo et al 2010a; b) and also recently addressed in a field study with S. solea (Jebali et al., 2013). In the actual context of climate change, and in an anthropogenic-impacted environment, a greater adaptability of one species in respect to a sympatric one, such is the case of both sole species, would be of great ecological significance. Recent studies have revealed a great adaptability of $S$. senegalensis to temperature variations (Arjona et al., 2010; Siscar et al., 2014; Solé et al., 2015) and different in vitro pesticide sensitivity in juveniles and adults of both species (Sánchez-Nogué et al., 2012; Koenig et al., 2013). However, under field conditions and using a multibiomarker set of parameters and target organs, there is need to simplify the large number of variables considered by means of using a data reduction technique whereby new variables, principal components analyses (PCA), calculated from linear combinations of the original variables.

The pesticides dichlorvos and diazinon were selected to contrast muscle acetylcholinesterase (AChE) sensitivity and the potential protective role of CbEs 
(Wheelock et al., 2008) in both sole. In S. senegalensis, AChE (EC 3.1.1.7) is predominant in brain and muscle and $\mathrm{CbE}$ (EC 3.1.1.1) is more abundant in liver (Solé et al., 2012). AChE is involved in neural transmission and CbE catalyses the hydrolysis of a wide range of xenobiotic esters, amides and thioesters. Due to its toxic action over non-target species, dichlorvos commercialisation has been banned in the EU (ECC directive 1376/07 (07/387)). However, the pesticide diazinon, due to its higher lipophilic character and current use, is found in the environment and bioaccumulated in sole from estuarine and marine areas (Sánchez-Nogué et al., 2012; Ben Ameur et al., 2013). Dichlorvos does not require metabolic activation to be toxic, whereas diazinon needs to be metabolised to the oxon form (by cytochrome P450 enzymes) to be able to inhibit AChE.

The aim of the present study was to contrast the enzymatic biomarker responses of liver and gill in two sole species sampled from several Mediterranean fishing grounds considered from low to moderately polluted. Site characterisation was derived from the organic pollutants present in sediment (Solé et al., 2013) and metals in the kidney of these same fish species (Siscar et al., 2013). The response of the two sole species to environmental pollutants was contrasted and their use as adequate sentinels discussed.

\section{Material and methods}

\subsection{Study area and sample collection}

Six fishing grounds located in the Catalan coast, NW Mediterranean, were selected for the study. The sites were from North to South: Costa Brava, Maresme, Garraf, Vendrell, Tarragona and Cambrils (Table 1 for coordinates). Fish sampling was carried out between January and March 2011 using gillnets at the six fishing areas with the collaboration of local artisanal fishermen. After sampling, the fish were immediately 
transported alive to a nearby laboratory in a refrigerated and aerated recipient container, and once there, biological parameters (total length and total weight) were recorded. Immediately after sacrifice, fish were dissected and their sex determined. Sample tissues of muscle, liver and gills, were fast frozen in liquid $\mathrm{N}_{2}$ and maintained at $-80^{\circ} \mathrm{C}$ for biomarker analysis. Handling of the fish was done according to national and institutional regulations of the Spanish Council for Scientific Research (CSIC) and the European Directive 2010/63/EU.

\subsection{Sample preparation}

A portion of individual liver and gills $(\approx 0.2-0.3 \mathrm{~g})$ were homogenised in ice-cold $100 \mathrm{mM}$ buffer phosphate (pH 7.4) containing $150 \mathrm{mM} \mathrm{KCl}, 1 \mathrm{mM}$ dithiothreitol (DTT), $\quad 0.1 \mathrm{mM}$ phenanthroline, $0.1 \mathrm{mg} / \mathrm{ml}$ trypsin inhibitor and $1 \mathrm{mM}$ ethylenediaminetetraacetic acid (EDTA) at a 1:4 (w:v) ratio using a polytron® blender. The homogenate was centrifuged at $10,000 \mathrm{~g} \mathrm{x} 30^{\prime}$ at $4^{\circ} \mathrm{C}$. The supernatant obtained (S10) was used for the enzymatic determinations.

\subsection{Analysis of hepatic and gill biomarkers}

Assay conditions were kept similar and only the sample volume was changed in order to achieve linearity in the enzymatic measurements. All assays were carried out in triplicate at $25^{\circ} \mathrm{C}$, except EROD which was at $30^{\circ} \mathrm{C}$, in 96 -wellplates using a TECAN Infinite M200 microplate reader.

Carboxylesterase (CbE) activity was measured in the S10 fraction, either 5-fold (gills) or 20-fold (liver) diluted. In each case, $25 \mu 1$ of sample and $200 \mu 1$ of $\alpha \mathrm{NA}$ as substrate $(250 \mu \mathrm{M}$ final concentration in well) were measured during $5 \mathrm{~min}$ at $235 \mathrm{~nm}(\varepsilon$ 
$=23.4 \mathrm{mM}^{-1} * \mathrm{~cm}^{-1}$ ) as described in Mastropaolo and Yourno (1981). Activity was expressed in $\mathrm{nmol} / \mathrm{min} / \mathrm{mg}$ protein.

7-ethoxyresorufin O-deethylase (EROD) activity was measured using $50 \mu \mathrm{l}$ of undiluted liver and gill homogenate samples (S10) and incubated at $30^{\circ} \mathrm{C}$ with a reaction mixture containing: $0.2 \mathrm{mM} \mathrm{NADPH}, 3.3 \mu \mathrm{M}$ 7-ethoxyresorufin (ER) in 100 mM phosphate buffer pH 7.4 (Burke and Mayer 1974). The reaction was followed over resorufin formation for $10 \mathrm{~min}$ in a 96-well plate using the fluorescence mode set at 537 $\mathrm{nm}$ excitation and $583 \mathrm{~nm}$ emission. A six-point standard curve of resorufin $(0-160 \mathrm{nM})$ was used to measure activity as $\mathrm{pmol} / \mathrm{min} / \mathrm{mg}$ protein. A good agreement between $\mathrm{S} 10$ and microsomal EROD activity determinations was formerly identified ( $r=0.951 ; n=12)$.

Glutathione $S$-transferase (GST) activity was measured in $25 \mu 1$ of diluted S10 5fold (gill) and 20-fold (liver), using 1-chloro-2,4-dinitrobenzene (CDNB) as substrate. The final reaction mixture contained $1 \mathrm{mM} C D N B$ and $1 \mathrm{mM}$ reduced glutathione (GSH). Activity was measured for $5 \mathrm{~min}$ at $340 \mathrm{~nm}\left(\varepsilon=9.6 \mathrm{mM}^{-1} * \mathrm{~cm}^{-1}\right)$ according to the Habig et al. (1974) method, and expressed as nmol/min/mg protein.

Catalase (CAT) activity was measured by a decrease in absorbance at $240 \mathrm{~nm}$ for 1 min using $50 \mathrm{mM} \mathrm{H}_{2} \mathrm{O}_{2}$ as substrate $\left(\varepsilon=40 \mathrm{M}^{-1} * \mathrm{~cm}^{-1}\right)$ following adaptation to Aebi (1984) protocol. Activity was expressed as $\mu \mathrm{mol} / \mathrm{min} / \mathrm{mg}$ protein.

Glutathione reductase (GR) activity was measured by a decrease in absorbance at $340 \mathrm{~nm}$ for $3 \mathrm{~min}$ using $0.9 \mathrm{mM}$ oxidized glutathione (GSSG) and $0.09 \mathrm{mM}$ nicotinamide adenine dinucleotide phosphate (NADPH) after microplate adaptation to the Carlberg and Mannervik (1985) protocol. Total glutathione-peroxidase (GPX) activity was also determined by a decrease in absorbance at $340 \mathrm{~nm}$ during $3 \mathrm{~min}$ using $2.5 \mathrm{mM}$ reduced glutathione (GSH), 1 Unit glutathione reductase (GR), $0.625 \mathrm{mM}$ cumene hydroperoxide (CHP) and $0.3 \mathrm{mM}$ NADPH modified for microplate from the 
Flohé and Günzle (1984) method. In both cases, $\varepsilon=6.22 \mathrm{mM}^{-1} * \mathrm{~cm}^{-1}$ and activity was expressed as $\mathrm{nmol} / \mathrm{min} / \mathrm{mg}$ protein.

Total protein content of the samples for all assays was determined by the Bradford method (1976) adapted to microplate, using Bradford Bio-Rad Protein Assay reagent and bovine serum albumin (BSA) as standard (0.1-1 mg/ml). Absorbance was read at $595 \mathrm{~nm}$.

\section{4. in vitro responses to pesticides.}

A portion of muscle, liver and gill of 4 specimens of $S$. solea and 4 of $S$. senegalensis ( 2 males and 2 females) was chosen for the assessment of in vitro response to 2 pesticides: dichlorvos (2,2-dichlorovinyl dimethyl phosphate, CAS no. 62-73-7) and diazinon (O,O-diethyl-O-(6-methyl-2-\{1-methylethyl $\}$-4-pirimidinyl phosphorothioate; CAS no. 333-41-5) both provided by Pestanal® (Fluka-SigmaAldrich, Madrid). About $0.3 \mathrm{~g}$ of each tissue were homogenised in ice-cold buffer phosphate $(50 \mathrm{mM} \mathrm{pH} \mathrm{7.4)}$ at a $1: 5(\mathrm{w}: \mathrm{v})$ ratio. The homogenates obtained were centrifuged at $10,000 \mathrm{~g}$ x $30 \mathrm{~min}(\mathrm{~S} 10)$. Incubations with the pesticides ranged from 1000 to $0.01 \mu \mathrm{M}$. Dichlorvos was diluted in water and diazinon in ethanol. $\mathrm{CbE}$ was measured using $\alpha \mathrm{NA}$ as substrate. For each incubation, carried out at room temperature $\left(23^{\circ} \mathrm{C}\right)$ and lasting $30 \mathrm{~min}, 120 \mu \mathrm{l}$ of sample appropriately diluted were mixed with $5 \mu \mathrm{l}$ of the respective stock pesticide to achieve the desired final concentration. Subsequently, we measured activities of AChE in muscle (Ellman et al., 1961) and CbE ( $\alpha \mathrm{NA})$ in liver and gills, as described above.

\subsection{Statistical analysis}


Data were checked for normality (Kolmogorof-Smirnof test) and homogeneous variance (Levene's test) and transformed, when needed, to comply with normality and homocedasticity assumptions. Pearson correlation coefficients were calculated between biomarker responses in the two organs (liver and gills) in order to measure the strength of association between these responses for each species separately. The influence of fish size was assessed by the correlation between this parameter and the biomarker responses, and if significant, ANCOVA tests were performed. The influence of fish sex was tested by General Linear Model contrasts considering the two species separately. In S. solea ANOVA/ANCOVA tests were performed when contrasting site differences in enzymatic activities. In S. senegalensis t-test/ANCOVA contrasts were chosen as only two sites were contrasted. A principal component analysis (PCA) was applied using all the biomarkers in order to evaluate the relationships between the enzymatic activities in the two solea species independently. Student's t-test contrasts were used to test for differences between species after in vitro incubation at a given concentration of dichlorvos. All statistical analyses were carried out using SPSS Systems (SPSS Inc., v19) and the significance level was always set at $\alpha=0.05$.

\section{Results}

The coordinates of the selected sampling sites and the fish biological traits are presented in Table 1. The statistical analysis performed for each biomarker and tissue is indicated in Table 2. In Table 3 the results of the PCA analysis for all biomarkers measured in liver and gills are presented and, in Table 4, the biomarker correlation coefficient results for each species in the two contrasted tissues are indicated. Enzyme activities corresponding to both species and tissues are presented in figures: phase I and phase II activities (Fig. 1) and antioxidant enzymes (Fig. 2). All values are expressed as 
mean \pm SEM. Site differences for $S$. solea (white bars) and S. senegalensis (stripped bars) are indicated after ANOVA/ANCOVA contrasts in $S$. solea (5 sampled sites) and t-test/ANCOVA in S. senegalensis (2 sites).

\subsection{Biomarker responses in S. solea}

In Fig. 1 (white bars), phase I EROD activity in liver (in pmol/min/mg prot) varied from 0.8 to 2.57 and in gills (in fmol/min/mg prot) from 93.3 to 171.1 with no significant site differences in both tissues. $\mathrm{CbE}$ (in nmol/min mg prot) ranged from 82.6 to 108.6 in liver and from 5.2 to 7.0 in gills showing no site differences either in any tissue. Phase II GST (in nmol/min/mg prot) varied from 255.9 to 509.9 in liver and from 48.2 to 106.5 in gills but not significantly $(\mathrm{p}>0.05)$.

In Fig 2 (white bars), antioxidant defences such as catalase (in $\mu \mathrm{mol} / \mathrm{min} / \mathrm{mg}$ prot) varied from 179.4 to 302.6 in liver and in gills from 14.4 to 26.3 , in both cases Garraf site showed the highest activity $(\mathrm{p}<0.05)$. GR and GPX activities (in $\mathrm{nmol} / \mathrm{min} / \mathrm{mg}$ prot) were dominant in gills in the case of GR (48.3-114.6) in respect to liver (12.5-21.9) but GPX activity was similar in both tissues. That is in liver, GPX ranged from 64.3 to 133.0 and in gills from 95.6 to 106.0. Site differences depended on the activity and tissue. They were confirmed in hepatic GPX after ANOVA and, in both tissues, for GR activity after ANCOVA contrasts.

In Table 3 PCA analysis revealed that the antioxidant enzymes were the parameters more significant in site discrimination in S. solea.

\subsection{Biomarker responses in S. senegalensis}

This species was only fished in two sites: Costa Brava and Garraf (Fig. 1 stripped bars). EROD activity in both tissues was significantly elevated in the Garraf 
site but only reached significance in gills ( $\mathrm{t}$-test; $\mathrm{p}<0.05)$. CbE activity in liver was about 7-fold higher than in gills, with no site related differences in either tissue. GST was also about 6-fold higher in liver than in gills but with no site associated differences, either.

As far as antioxidant defences concern (Fig. 2 stripped bars), they also followed the same trend as in $S$. solea in quantitative terms of enzyme activities per tissue. As per site, GR activity in liver was elevated in the northern site of Costa Brava whereas in the central site Garraf, GPX in gills and CAT in liver were significantly elevated $(\mathrm{p}<0.05)$.

In Table 3 PCA analysis revealed that activities of EROD in both tissues and hepatic GST were the parameters more determinant in site discrimination in $S$. senegalensis.

\subsection{Correlations between gill and liver biomarkers}

Pearson correlation coefficient was calculated separately in each species for all biomarker responses in both tissues (Table 4). In S. solea $(\mathrm{n}=48)$ the most significant positive correlations were between all GSH related activities: GST, GR and GPX $(\mathrm{r}=0.608-0.658 ; \mathrm{p}<0.001)$ as well as between the antioxidants CAT and GPX $(\mathrm{r}=0.419$; $\mathrm{p}<0.01)$ in liver. In gill GR and GST correlation was significant $(r=0.462 ; \mathrm{p}<0.001)$ as well as between $\mathrm{CbE}$ and the antioxidants GR $(r=0.368$; $\mathrm{p}<0.01)$ and GST $(r=0.486$; $\mathrm{p}<0.001)$.

In $S$. senegalensis $(\mathrm{n}=23)$, correlation coefficients were even stronger. Mostly between EROD activity in liver and gill $(\mathrm{r}=0.637$; $\mathrm{p}<0.001)$. In liver, correlations were observed between phase I EROD and $\mathrm{CbE}(\mathrm{r}=0.592 ; \mathrm{p}<0.01)$ but also phase I EROD and phase II GST $(\mathrm{r}=0.649 ; \mathrm{p}<0.001)$. The antioxidants CAT and GPX $(\mathrm{r}=0.580$; $\mathrm{p}<0.05)$ as well as GST and GPX $(\mathrm{r}=0.534 ; \mathrm{p}<0.05)$ were also correlated in liver. In this 
same organ, $\mathrm{CbE}$ activity also correlated to the antioxidants $(\mathrm{p}<0.05)$ catalase $(\mathrm{r}=0.443)$ and GPX (r=0.480). In gills, CbE and GST activities correlated $(r=0.601 ; \mathrm{p}<0.01)$ and also the antioxidants GR and GPX $(r=0.551 ; \mathrm{p}<0.01)$.

\subsection{Esterase responses after in vitro pesticide incubations}

Muscle AChE activity (Fig. 3a) was inhibited at a different extent in either sole species after dichlorvos incubations, mainly in the $0.1-10 \mu \mathrm{M}$ range. Similarly, in liver, $\mathrm{CbE}$ showed species differences within this pesticide range (Fig. 3b). By contrast, in gills the degree of inhibition of $\mathrm{CbE}$ was already evident at $0.01 \mu \mathrm{M}$ confirming greater species differences (Fig. 3c).

Diazinon (data not shown) inhibited muscular AChE at only concentrations above $100 \mu \mathrm{M}$. The degree of inhibition reached in $S$. solea at the highest dose $(1 \mathrm{mM})$ was $66 \%$ for $S$. solea and $23 \%$ in S. senegalensis, suggesting that common sole is more sensitive to this pesticide. In liver $\mathrm{CbE}$ was only differentially inhibited at the highest 1 $\mathrm{mM}$ concentration with a lower gap in their degree of inhibition: $S$ solea $(58 \%)$ and $S$. senegalensis $(77 \%)$.

\section{Discussion}

The sites selected for the study correspond to fishing grounds regularly targeted by local fishermen. Previous studies carried out in these same fishing sites revealed they corresponded to low and moderately polluted sites in terms of organic and inorganic contaminants, as indicated by the analysis of sediment and certain bioaccumulated chemicals (Solé et al., 2013; Siscar et al., 2013). In agreement with these former chemical observations, no great site differences were revealed for most parameters measured in S. solea; nonetheless, the increased activity of some enzymes in the central 
stations of Maresme and Garraf (North and South of Barcelona urban area) agreed with higher presence of some metals in the kidney of these fish and some altered immunological parameters (Solé et al., 2013; Siscar et al., 2013). Also, in line with former observations, site differences were more evident in S. senegalensis as sampling sites for this species corresponded to more distant geographical areas; which also pointed out the higher chemical exposure in the central site of Garraf,reflected in the hepatic and gill biomarker responses presented here but also earlier (Solé et al., 2013; Siscar et al., 2013). However, in the interpretation of the present results, caution must be taken due to the influence of biological variables such as fish size and sex that may act as confounding factors. In these situations, which are frequently encountered in field studies, multifactorial and ANCOVA tests are recommended (Costa et al., 2012; Koenig and Solé, 2012). PCA analysis also supported limited site discrimination by biomarker responses due to the small pollution gradient between sites.

The influence of physical parameters such as temperature can also modulate these enzymatic responses as formerly seen in S. senegalensis (Fonseca et al., 2011b; Solé et al., 2015). Nonetheless,, little variation in temperature was seen in the selected fishing grounds at the time of sampling. By contrast, the influence of biological parameters such as fish size and sex was more noticeable. In S. solea, bigger specimens displayed higher activities of GST and GR in both organs. Fish sex strongly influenced EROD activity in liver in both species with males expressing higher activity than females. This is a well-known trait in fish as EROD activity is modulated by the female sex hormone estradiol (Whyte et al., 2000). In the same species, S. solea, gill GST activity in females $(n=30)$ was higher than in males $(n=17)$ but, in this case, it could also be due to the larger size of females. By contrast, in S. senegalensis, GST in liver but also CAT in gill were also significantly higher in males $(n=15)$ than females $(n=6)$, 
regardless of sampling site and contrasting individuals of similar body size. Despite this, limitations in the sample size require taking these relationships with caution.

Enzymatic activities in the two tested organs were, in general and as expected, higher in liver than in gills, as the former is the most important detoxification organ, as described in S. solea (Jebali et al., 2013), S. senegalensis (López-Galindo et al., 2010a, b), and in eel, Anguilla anguilla (Regoli et al., 2011) The only enzyme to display higher activity in gills was the antioxidant GR, a trend also seen in A. anguilla (Regoli et al., 2011). In the study with $A$. anguilla, higher site-related chemical differences were reported, even between the considered moderately polluted site in respect to its control, and this was reflected in stronger biomarker response differences. The little responsiveness for most biomarkers in relation to pollution in the present Solea spp. study is likely due to the small pollution gradient between sites, more significantly in $S$. solea. In a previous study with $S$. senegalensis, biomarker responses were more marked when fish were exposed, in the lab, to the sediment from the moderately polluted Sado estuary of Portugal rather that when local fish were contrasted in situ (Gonçalves et al., 2013). Despite little site differences in the biomarker responses of the present study, the good agreement between phase I and II responses, especially in S. senegalensis confirms the initiation of the metabolic machinery as a consequence of chemical exposure as well as effects on the antioxidant defences. In particular, EROD activity in gill, regardless of its low hydrolysis ratio, seemed more responsive to pollution and it was less affected by biological traits such as size and sex, in respect to liver. More controversial is the response of GST and antioxidant defences to environmental chemical exposure, as demonstrated here and in other studies with Solea spp. (Jebali et al., 2010; Fonseca et al., 2011a; Oliva et al., 2012).Results derived from PC analysis (Table 3) of antioxidant defences were the parameters to account for site discrimination 
in S. solea, whereas EROD and GST in liver were the main factors in discriminating for

S. senegalensis. In addition, there was a good agreement in the response of the battery of enzymes selected, as indicated by their good correlation coefficients (Table 4).

Little is known about the modulation in fish of $\mathrm{CbE}$ activities by chemicals, other than organophosphorous (OP) pesticides (Wheelock et al., 2008). CbE comprises a multigene family of enzymes with broad substrate specificity which binds to pesticides, in some cases with greater affinity than AChE. The substrate $\alpha \mathrm{NA}$ is more specific for OP pesticides, also formerly evidenced in S. senegalensis (Solé et al., 2012; Koenig et al., 2013). CbE activity in liver was higher than in gills, as expected, but the presystemic metabolism in gills is of great relevance as it would influence the bioaccumulation of environmental contaminants containing esters (Barron et al., 1999). In this study the inhibitory capacity of two pesticides with different mechanistic action was contrasted: dichlorvos does not require metabolic activation to be toxic whereas the more persistent and bioaccumulable diazinon does. Accordingly, inhibition of muscular AChE by diazinon was only reached at very high doses $(>100 \mu \mathrm{M})$ whereas dichlorvos was already responsible for enzyme inhibition at more realistic environmental doses $(<1$ $\mu \mathrm{M})$; although due to its current ban, this pesticide is not environmentally detected nowadays. However, dichlorvos was selected as a pesticide frequently used to contrast species sensitivity. The species differences encountered here were coincident with former observations with juveniles and adults of this same species (Sánchez-Nogué et al., 2012; Koenig et al., 2013) and extended, in this study, to gill CbE. In either case, $S$. solea was more sensitive to AChE inhibition by OP pesticides, and this greater responsiveness was reflected with a greater $\mathrm{CbE}$ affinity for dichlorvos in liver and gills. Thus, the action of $\mathrm{CbE}$ could aid in preventing neurotoxic damage in the apparently more sensitive $S$. solea. 
Present results and those derived from other field and/or laboratory studies (López-Galindo et al., 2010a, b; Costa et al., 2012; Ribecco et al., 2012; Jebali et al., 2013; Gonçalves et al., 2013; Solé et al., 2014) with Solea sp., support the use of these species as alternative benthic species for monitoring studies in Southern Europe (Table 5). Using a multibiomarker approach and two target tissues, both sole species were consistent in their biomarker responses and were able to reflect site differences even if the pollution gradient was low and the magnitude of biomarker changes was about 2-3 fold. The sedentary habits of these species, their economic interest and moderate but consistent response to pollutants warrant its consideration as adequate sentinels in Southern Europe. Nonetheless, further confirmation under other field situations with greater pollution gradients, with more individuals of comparable biological traits and the influence of physical environmental parameters on biomarker responses is advisable.

\section{Conclusions}

In field studies where fish are exposed to complex chemical mixtures but with no great pollution gradients, the influence of biological traits such as size and sex can act as confounding factors in the biomarker responses. In spite of the application of a battery of biomarkers of exposure embracing two target tissues, liver as main metabolic organ and gills as the first to respond to water-borne exposure, all pointed out in the same direction. Both solea species seemed equally adequate as sentinels and the better results attained with $S$. senegalensis were due to greater gradient of chemical exposure.

\section{Acknowledgements}


This work was financed by the Ministry of Science and Innovation of Spain (ref CTM2010-16611).

\section{References}

Aebi, H., 1984. Catalase in vitro. Methods in Enzymology 105, 121-126.

Akcha, F., Hubert, F.V., Pfhol-Leszkowicz, A., 2003. Potential value of the comet assay and DNA adduct measurement in dab (Limanda limanda) for assessment of in situ exposure to genotoxic compounds. Mutation Research-Genetic Toxicology and Environmental Mutagenesis 534, 21-32.

Arjona, F.J., Ruiz-Jarabo, I., Vargas-Chacoff, L., del Rio, M.P.M., Flik, G., Mancera, J.M., Klaren, P.H.M., 2010. Acclimation of Solea senegalensis to different ambient temperatures: implications for thyroidal status and osmoregulation. Marine Biology 157, 1325-1335.

Barron, M.G., Charron, K.A., Stott, W.T., Duvall, S.E., 1999. Tissue carboxylesterase activity of rainbow trout. Environmental Toxicology and Chemistry 18, 25062511.

Ben Ameur, W., El Megdiche, Y., Eljarrat, E., Ben Hassine, S., Badreddine, B., Souad, T., Bechir, H., Barcelo, D., Driss, M.R., 2013. Organochlorine and organobromine compounds in a benthic fish (Solea solea) from Bizerte Lagoon (northern Tunisia): Implications for human exposure. Ecotoxicology and Environmental Safety 88, 55-64. 
Bradford, M.M., 1976. A rapid and sensitive method for the quantitation of microgram quantities of protein utilizing the principle of protein-dye binding. Analytical Biochemistry 72, 248-254.

Burke, M.D., Mayer, R.T., 1974. Ethoxyresorufin - direct fluorimetric assay of a microsomal $O$-dealkylation which is preferentially inducible by 3 methylcholanthrene. Drug Metabolism and Disposition 2, 583-588.

Carlberg, I., Mannervik, B., 1985. Glutathione-reductase. Methods in Enzymology 113, 484-490.

Costa, P.M., Diniz, M.S., Caeiro, S., Lobo, J., Martins, M., Ferreira, A.M., Caetano, M., Vale, C., DelValls, T.Á., Costa, M.H., 2009. Histological biomarkers in liver and gills of juvenile Solea senegalensis exposed to contaminated estuarine sediments: A weighted indices approach. Aquatic Toxicology 92, 202-212.

Costa, P.M., Caeiro, S., Diniz, M.S., Lobo, J., Martins, M., Ferreira, A.M., Caetano, M., Vale, C., DelValls, T.Á., Costa, M.H., 2010. A description of chloride cell and kidney tubule alterations in the flatfish Solea senegalensis exposed to moderately contaminated sediments from the Sado estuary (Portugal). Journal of Sea Research 64, 465-472.

Costa, P.M., Caeiro, S., Vale, C., DelValls, T.À., Costa, M.H., 2012. Can the integration of multiple biomarkers and sediment geochemistry aid solving the complexity of sediment risk assessment? A case study with a benthic fish. Environmental Pollution 161, 107-120. 
Dierking, J., Wafo, E., Schembri, T., Lagadec, V., Nicolas, C., Letourneur, Y., Harmelin-Vivien, M., 2009. Spatial patterns in PCBs, pesticides, mercury and cadmium in the common sole in the NW Mediterranean Sea, and a novel use of contaminants as biomarkers. Marine Pollution Bulletin 58, 1605-1614.

Ellman G.L., Courtney K.D., Andres Jr. V., Featherstone R.M., 1961. A new and rapid colorimetric determination of acetylcholinesterase activity. Biochemical Pharmacology 7, 88-9.

Flohe, L., Gunzler, W.A., 1984. Assays of glutathione-peroxidase. Methods in Enzymology 105, 114-121.

Fonseca, V.F., França, S., Serafim, A., Company, R., Lopes, B., Bebianno, M.J., Cabral, H.N., 2011a. Multi-biomarker responses to estuarine habitat contamination in three fish species: Dicentrarchus labrax, Solea senegalensis and Pomatoschistus microps. Aquatic Toxicology 102, 216-227.

Fonseca V.F., Franca S., Vasconcelos R.P., Serafim A., Company R., Lopes B., Bebianno M.J., Cabral H.N., 2011b. Short-term variability of multiple biomarker response in fish from estuaries: Influence of environmental dynamics. Marine Environmental Research 72, 172-178.

Gonçalves, C., Martins, M., Costa, M.H., Caeiro, S., Costa, P.M., 2013. Ecological risk assessment of impacted estuarine areas: Integrating histological and biochemical endpoints in wild Senegalese sole. Ecotoxicology and Environmental Safety 95, 202-211. 
Gonçalves, C., Martins, M., Diniz, M.S., Costa, M.H., Caeiro, S., Costa, P.M., 2014. May sediment contamination be xenoestrogenic to benthic fish? A case study with Solea senegalensis. Marine Environmental Research 99, 170-178.

Habig, W.H., Pabst, M.J., Jakoby, W.B., 1974. Glutathione S-Transferases. The Journal of Biological Chemistry 249, 7130-7139.

Imsland, A.K., Foss, A., Conceicao, L.E.C., Dinis, M.T., Delbare, D., Schram, E., Kamstra, A., Rema, P., White, P., 2003. A review of the culture potential of Solea solea and S. senegalensis. Reviews in Fish Biology and Fisheries 13, 379407.

Koenig, S., Sole, M., 2012. Natural variability of hepatic biomarkers in Mediterranean deep-sea organisms. Marine Environmental Research 79, 122-131.

Koenig, S., Guillen, K., Solé, M., 2013. Comparative xenobiotic metabolism capacities and pesticide sensitivity in adults of Solea solea and Solea senegalensis. Comparative Biochemistry and Physiology C 157, 329-336.

Kopecka, J., Pempkowiak, J., 2008. Temporal and spatial variations of selected biomarker activities in flounder (Platichthys flesus) collected in the Baltic proper. Ecotoxicology and Environmental Safety 70, 379-391.

Jebali, J., Sabbagh, M., Banni, M., Kamel, N., Ben-Khedher, S., M'Hamdi, N., Boussetta, H., 2013. Multiple biomarkers of pollution effects in Solea solea fish on the Tunisia coastline. Environmental Science and Pollution Research 20, $3812-3821$. 
Lehtonen, K.K., Schiedek, D., Kohler, A., Lang, T., Vuorinen, P.J., Forlin, L., Barsiene, J., Pempkowiak, J., Gercken, J., 2006. The BEEP project in the Baltic Sea: Overview of results and outline for a regional biological effects monitoring strategy. Marine Pollution Bulletin 53, 523-537.

Lerebours, A., Stentiford, G.D., Lyons, B.P., Bignell, J.P., Derocles, S.A.P., Rotchell, J.M., 2014. Genetic Alterations and Cancer Formation in a European Flatfish at Sites of Different Contaminant Burdens. Environmental Science \& Technology $48,10448-10455$.

López-Galindo, C., Vargas-Chacoff, L., Nebot, E., Casanueva, J.F., Rubio, D., Solé, M., Mancera, J.M., 2010a. Biomarker responses in Solea senegalensis exposed to sodium hypochlorite used as antifouling. Chemosphere 78, 885-893.

López-Galindo, C., Vargas-Chacoff, L., Nebot, E., Casanueva, J.F., Rubio, D., Solé, M., Mancera, J.M., 2010b. Sublethal effects of the organic antifoulant Mexel (R) 432 on osmoregulation and xenobiotic detoxification in the flatfish Solea senegalensis. Chemosphere 79, 78-85.

Mastropaolo, W., Yourno, J., 1981. An ultraviolet spectrophotometric assay for alphanaphthyl acetate and alpha-naphthyl butyrate esterases. Analytical Biochemistry $115,188-193$.

Napierska, D., Podolska, M., 2005. Biomarkers of contaminant exposure: results of a field study with flounder (Platichthys flesus) from the southern Baltic Sea. Marine Pollution Bulletin 50, 758-767. 
Oliva, M., de Canales, M.L.G., Gravato, C., Guilhermino, L., Perales, J.A., 2010. Biochemical effects and polycyclic aromatic hydrocarbons (PAHs) in Senegal sole (Solea senegalensis) from a Huelva estuary (SW Spain). Ecotoxicology and Environmental Safety 73, 1842-1851.

Oliva, M., Vicente, J.J., Gravato, C., Guilhermino, L., Galindo-Riano, M.D., 2012. Oxidative stress biomarkers in Senegal sole, Solea senegalensis, to assess the impact of heavy metal pollution in a Huelva estuary (SW Spain): Seasonal and spatial variation. Ecotoxicology and Environmental Safety 75, 151-162.

Regoli, F., Giuliani, M.E., Benedetti, M., Arukwe, A., 2011. Molecular and biochemical biomarkers in environmental monitoring: A comparison of biotransformation and antioxidant defense systems in multiple tissues. Aquatic Toxicology 105, $56-66$.

Ribecco, C., Hardiman, G., Sasik, R., Vittori, S., Carnevali, O., 2012. Teleost fish (Solea solea): A novel model for ecotoxicological assay of contaminated sediments. Aquatic Toxicology 109, 133-142.

Sànchez-Nogué, B., Varó, I., Solé, M., 2013. Comparative analysis of selected biomarkers and pesticide sensitivity in juveniles of Solea solea and Solea senegalensis. Environmental Science Pollution Research 20, 3480-3488.

Siscar, R., Torreblanca, A., Palanques, A., Sole, M., 2013. Metal concentrations and detoxification mechanisms in Solea solea and Solea senegalensis from NW Mediterranean fishing grounds. Marine Pollution Bulletin 77, 90-99. 
Siscar, R., Torreblanca, A., del Ramo, J., Sole, M., 2014. Modulation of metallothionein and metal partitioning in liver and kidney of Solea senegalensis after long-term acclimation to two environmental temperatures. Environmental Research 132, 197-205.

Solé, M., Vega, S., Varó, I., 2012. Characterization of type "B" esterases and hepatic CYP450 isoenzimes in Senegalese sole for their further application in monitoring studies. Ecotoxicology and Environmental Safety 78, 72-79.

Solé, M., Manzanera, M., Bartolomé, A., Tort, L., Caixach, J., 2013. Persistent organic pollutants (POPs) in sediments from fishing grounds in the NW Mediterranean: Ecotoxicological implications for the benthic fish Solea sp. Marine Pollution Bulletin 67, 158-165.

Sole, M., Fortuny, A., Mananos, E., 2014. Effects of selected xenobiotics on hepatic and plasmatic biomarkers in juveniles of Solea senegalensis. Environmental Research 135, 227-235.

Sole, M., Varo, I., Gonzalez-Mira, A., Torreblanca, A., 2015. Xenobiotic metabolism modulation after long-term temperature acclimation in juveniles of Solea senegalensis. Marine Biology 162, 401-412. (Sole et al., 2014)

Trisciani, A., Corsi, I., Torre, C.D., Perra, G., Focardi, S., 2011. Hepatic biotransformation genes and enzymes and PAH metabolites in bile of common sole (Solea solea, Linnaeus, 1758) from an oil-contaminated site in the Mediterranean Sea: A field study. Marine Pollution Bulletin 62, 806-814. 
van der Oost, R., Beyer, J., Vermeulen, N.P.E., 2003. Fish bioaccumulation and biomarkers in environmental risk assessment: a review. Environmental Toxicology and Pharmacology 13, 57-149.

Vinagre, C., Narciso, L., Pimentel, M., Cabral, H.N., Costa, M.J., Rosa, R., 2013. Contrasting impacts of climate change across seasons: effects on flatfish cohorts. Regional Environmental Change 13, 853-859.

Wheelock, C.E., Phillips, B.M., Anderson, B.S., Mille,r J.L., Miller, M.J., Hammock, B.D., 2008. Applications of carboxylesterase activity in environmental monitoring and toxicity identification evaluations (TIEs). Reviews of Environmental Contamination and Toxicology 195, 117-178.

Whyte, J.J., Jung, R.E., Schmitt, C.J., Tillitt, D.E., 2000. Ethoxyresorufin-O-deethylase (EROD) activity in fish as a biomarker of chemical exposure. Critical Reviews in Toxicology 30, 347-570.

Wessel, N., Santos, R., Menard, D., Le Menach, K., Buchet, V., Lebayon, N., Loizeau, V., Burgeot, T., Budzinski, H., Akcha, F., 2010. Relationship between PAH biotransformation as measured by biliary metabolites and EROD activity, and genotoxicity in juveniles of sole (Solea solea). Marine Environmental Research 69, S71-S73. 
Table 1. Sampling site and coordinates of the NW Mediterranean fishing grounds. Characteristics of the fish (Solea solea and Solea senegalensis) sampled in winter 2011 (January-March). Fish weight and length are indicated as mean \pm SD.

\begin{tabular}{lllccc}
\hline Fishing site & Coordinates & Species sampled & $\begin{array}{c}\text { Sex } \\
(\mathrm{M}: \mathrm{F})\end{array}$ & $\begin{array}{c}\text { Fish weight } \\
(\mathrm{g})\end{array}$ & $\begin{array}{c}\text { Fish length } \\
(\mathrm{cm})\end{array}$ \\
\hline Costa Brava & $42^{\circ} 01,505^{\prime} \mathrm{N} / 03^{\circ} 14,676^{\prime} \mathrm{E}$ & S. senegalensis & $7: 5$ & $548 \pm 160$ & $38.8 \pm 3.8$ \\
Maresme & $41^{\circ} 25,497^{\prime} \mathrm{N} / 02^{\circ} 18,765^{\prime} \mathrm{E}$ & S. solea & $1: 10$ & $631 \pm 179$ & $39.3 \pm 3.3$ \\
Garraf & $41^{\circ} 10,953^{\prime} \mathrm{N} / 01^{\circ} 54,716^{\prime} \mathrm{E}$ & S. solea & $3: 7$ & $600 \pm 193$ & $38.9 \pm 3.6$ \\
& & S. senegalensis & $7: 2$ & $415 \pm 83.6$ & $35.9 \pm 2.1$ \\
Vendrell & $41^{\circ} 08,056^{\prime} \mathrm{N} / 01^{\circ} 27,398^{\prime} \mathrm{E}$ & S. solea & $4: 9$ & $511 \pm 254$ & $36.6 \pm 5.0$ \\
Tarragona & $41^{\circ} 05,705^{\prime} \mathrm{N} / 01^{\circ} 18,782^{\prime} \mathrm{E}$ & S. solea & $3: 1$ & $273 \pm 59.2$ & $32.6 \pm 1.9$ \\
Cambrils & $41^{\circ} 00,511^{\prime} \mathrm{N} / 01^{\circ} 01,498^{\prime} \mathrm{E}$ & S. solea & $6: 3$ & $262 \pm 102$ & $30.8 \pm 3.4$ \\
\hline
\end{tabular}


Table 2. Statistics test applied to the biomarker site contrasts for each species (Solea solea and Solea senegalensis) and tissue (liver and gill). The influence of fish size and sex was measured by the use of the general linear model (GLM) with Pearson correlation coefficient $(\mathrm{R})$ to measure the strength of each variable and fish length and by the influence of sex by the F value after the ANOVA contrasts. ${ }^{*} \mathrm{p}<0.05 ; * * \mathrm{p}<0.01$ and $* * * \mathrm{p}<0.001$. N.S. not significant.

\begin{tabular}{llllllll}
\hline & & S. solea & Size effect & Sex effect & S. senegalensis & Size effect & Sex effect \\
\hline CbE & liver & ANOVA & N.S. & N.S. & T-TEST & N.S. & N.S. \\
& gill & ANOVA & N.S. & N.S. & T-TEST & N.S. & N.S. \\
EROD & liver & ANOVA & N.S. & F=18.590*** & ANCOVA & R=-0.593** & F=24.092*** \\
& gill & ANOVA & N.S. & N.S. & T-TEST & N.S. & N.S. \\
GST & liver & ANCOVA & R=0.308* & N.S. & T-TEST & N.S. & F=31.586*** \\
& gill & ANCOVA & R=0.612*** & F=17.844*** & ANCOVA & R=0.514* & N.S. \\
CAT & liver & ANOVA & N.S. & N.S. & T-TEST & N.S. & N.S. \\
& gill & ANOVA & N.S. & N.S. & T-TEST & N.S. & F=7.518* \\
GPX & liver & ANOVA & N.S. & N.S. & T-TEST & N.S. & N.S. \\
& gill & ANOVA & N.S. & N.S. & T-TEST & N.S. & N.S. \\
GR & liver & ANCOVA & R=0.293* & N.S. & T-TEST & N.S. & N.S. \\
& gill & ANCOVA & R=0.314* & N.S. & T-TEST & N.S. & N.S. \\
\hline
\end{tabular}


Table 3. Results of the score coefficients for the PCA analysis after orthogonal rotation (Varimax) with a Bartlett's test of sphericity $(\mathrm{p}<0.05)$ and Kaiser-Meyer-Olkin $(>0.60)$.

\begin{tabular}{lcc|lcc}
\hline S solea & 1 & 2 & S senegalensis & 1 & 2 \\
\hline GPX-liver & 0.885 & -0.051 & EROD-liver & 0.87 & 0.007 \\
GST-liver & 0.864 & 0.126 & GST-liver & 0.783 & -0.196 \\
GR-liver & 0.72 & -0.292 & EROD-gills & 0.74 & 0.007 \\
CAT-liver & 0.486 & 0.195 & CAT-liver & 0.687 & 0.352 \\
CAT-gills & 0.386 & -0.248 & GPX-liver & 0.668 & 0.139 \\
CbE-liver & 0.243 & -0.234 & CbE-liver & 0.643 & 0.322 \\
GPX-gills & -0.219 & -0.152 & GST-gills & -0.363 & 0.225 \\
GR-gills & -0.224 & 0.808 & GR-gills & 0.016 & 0.74 \\
GST-gills & 0.435 & 0.746 & GPX-gills & 0.261 & 0.662 \\
CbE-gills & 0.284 & 0.663 & CAT-gills & 0.009 & -0.661 \\
EROD-gills & -0.255 & 0.507 & CbE-gills & -0.147 & 0.598 \\
EROD-liver & -0.167 & 0.187 & GR-liver & -0.084 & -0.441 \\
Variance explained & $\mathbf{P C 1}$ & $\mathbf{P C 2}$ & Variance explained & PC1 & PC2 \\
\hline (\%) & 24.6 & 18.0 & (\%) & 30.25 & 18.0 \\
\hline
\end{tabular}


Table 4. Pearson correlation coefficient between biomarkers in liver and gill for each species independently: Solea solea (upper right) and Solea senegalensis (lower left). $* \mathrm{p}<0.05 ; * * \mathrm{p}<0.01$ and $* * * \mathrm{p}<0.001$. n.s $=$ non significant.

\begin{tabular}{|c|c|c|c|c|c|c|c|c|c|c|c|c|c|}
\hline \multirow{2}{*}{\multicolumn{2}{|c|}{$\begin{array}{r}\text { S. solea }(n=48) \\
\text { S. senegalensis }(n=23)\end{array}$}} & \multicolumn{2}{|c|}{ EROD } & \multicolumn{2}{|c|}{$\mathrm{CbE}$} & \multicolumn{2}{|c|}{ GST } & \multicolumn{2}{|c|}{ CAT } & \multicolumn{2}{|c|}{ GR } & \multicolumn{2}{|c|}{ GPX } \\
\hline & & liver & gill & Liver & gill & liver & gill & liver & gill & liver & gill & liver & gill \\
\hline \multirow[t]{2}{*}{ EROD } & \multirow{2}{*}{$\begin{array}{l}\text { liver } \\
\text { gill }\end{array}$} & & n.s & n.s & n.s & n.s & n.s & n.s & n.s & n.s & n.s & n.s & n.s \\
\hline & & $0.637 * * *$ & & n.s & n.s & n.s & n.s & n.s & n.s & n.s & $0.315^{*}$ & n.s & n.s \\
\hline \multirow[t]{2}{*}{$\mathrm{CbE}$} & liver & $0.592 * *$ & $0.440 *$ & & n.s & n.s & n.s & $0.341^{*}$ & n.s & n.s & n.s & n.s & n.s \\
\hline & gill & n.s & $\mathrm{n} . \mathrm{s}$ & n.s & & n.s & $0.486 * * *$ & n.s & $\mathrm{n} . \mathrm{s}$ & n.s & $0.368 * *$ & n.s & n.s \\
\hline \multirow[t]{2}{*}{ GST } & liver & $0.649 * * *$ & $0.478^{*}$ & n.s & n.s & & $0.488 * * *$ & $0.324 *$ & $0.322 *$ & $0.608 * * *$ & n.s & $0.658 * * *$ & n.s \\
\hline & gill & n.s & n.s & n.s & $0.601 * *$ & n.s & & n.s & n.s & n.s & $0.462 * * *$ & $0.300^{*}$ & $-0.301 *$ \\
\hline \multirow[t]{2}{*}{ CAT } & liver & n.s & n.s & $0.443^{*}$ & n.s & $0.483 *$ & n.s & & n.s & n.s & n.s & $0.419 * *$ & n.s \\
\hline & gill & n.s & n.s & n.s & n.s & n.s & n.s & n.s & & n.s & n.s & n.s & n.s \\
\hline \multirow[t]{2}{*}{ GR } & liver & n.s & n.s & n.s & n.s & n.s & n.s & n.s & $0.424 *$ & & $-0.318 *$ & $0.645 * * *$ & n.s \\
\hline & gill & n.s & n.s & n.s & $0.462 *$ & n.s & n.s & n.s & n.s & n.s & & n.s & n.s \\
\hline \multirow[t]{2}{*}{ GPX } & liver & n.s & n.s & $0.480 *$ & n.s & $0.534 * *$ & n.s & $0.580 * *$ & n.s & n.s & n.s & & n.s \\
\hline & gill & n.s & n.s & n.s & n.s & n.s & n.s & $0.414^{*}$ & n.s & n.s & $0.551 * *$ & n.s & \\
\hline
\end{tabular}


Table 5. Biomarkers in the S10 fraction of different tissues: liver and gill of Solea senegalensis and Solea solea. Units are in $\mathrm{nmol} / \mathrm{min} / \mathrm{mg}$ prot except CAT ( $\mu \mathrm{mol} / \mathrm{min} / \mathrm{mg}$ prot) and EROD (pmol/min/mg prot). n.a. not analysed. Range values are approximate as in some cases are extracted from figures.

\begin{tabular}{|c|c|c|c|c|c|c|c|c|c|c|}
\hline Species & Stage & Type of study & Tissue & EROD & GST & CAT & GPx & GR & CbE (aNA) & Reference \\
\hline S. senegalensis & Juveniles & $\mathrm{Lab}$ exposure to $\mathrm{NaCl}$ & $\begin{array}{l}\text { Liver } \\
\text { Gills }\end{array}$ & $\begin{array}{l}1.1-3.5 \\
\text { n.a. }\end{array}$ & $\begin{array}{l}370-450 \\
100-500\end{array}$ & $\begin{array}{c}229-449 \\
29-37\end{array}$ & $\begin{array}{l}\text { 94-104 } \\
\text { n.a. }\end{array}$ & $\begin{array}{l}9-16 \\
\text { n.a. }\end{array}$ & $\begin{array}{l}\text { n.a. } \\
\text { n.a. }\end{array}$ & Lopez-Galindo et al., 2010a \\
\hline S. senegalensis & Juveniles & Lab exposure to Mexel & $\begin{array}{l}\text { Liver } \\
\text { Gills }\end{array}$ & $\begin{array}{l}1.5-3.2 \\
\text { n.a. }\end{array}$ & $\begin{array}{l}353-414 \\
100-130\end{array}$ & $\begin{array}{c}140-240 \\
40-60\end{array}$ & $\begin{array}{l}101-138 \\
\text { n.a. }\end{array}$ & $\begin{array}{l}11-21 \\
\text { n.a. }\end{array}$ & $\begin{array}{l}\text { n.a. } \\
\text { n.a. }\end{array}$ & Lopez-Galindo et al.,2010b \\
\hline S. senegalensis & Juveniles & Lab. Exposure to diet $\& \mathrm{~T}^{\mathrm{a}}$ & Liver & n.a. & n.a. & $154-224$ & $14-38$ & $16-27$ & n.a. & Castro et al., 2012 \\
\hline $\begin{array}{l}\text { S. senegalensis } \\
\text { S. solea }\end{array}$ & $\begin{array}{l}\text { Juveniles } \\
\text { Juveniles }\end{array}$ & $\begin{array}{l}\text { Field: Sado estuary, Portugal } \\
\text { Field: Tunisia coastline }\end{array}$ & $\begin{array}{l}\text { Liver } \\
\text { Liver } \\
\text { Gills }\end{array}$ & $\begin{array}{l}\text { n.a. } \\
\text { n.a. } \\
\text { n.a. }\end{array}$ & $\begin{array}{c}100-300 \\
600-900 \\
100-150\end{array}$ & $\begin{array}{l}20-60 \\
25-60 \\
18-35\end{array}$ & $\begin{array}{l}\text { n.a. } \\
\text { n.a. } \\
\text { n.a. }\end{array}$ & $\begin{array}{l}\text { n.a. } \\
\text { n.a. } \\
\text { n.a. }\end{array}$ & $\begin{array}{l}\text { n.a. } \\
\text { n.a. } \\
\text { n.a. }\end{array}$ & Gonçalves et al., 2013 \\
\hline S. solea & Juveniles & Field: Ebre Delta & $\begin{array}{l}\text { Liver } \\
\text { Gills }\end{array}$ & $\begin{array}{l}1.3-3.2 \\
\text { n.a. }\end{array}$ & $\begin{array}{c}397-431 \\
52-88\end{array}$ & $\begin{array}{l}\text { n.a. } \\
\text { n.a. }\end{array}$ & $\begin{array}{l}\text { n.a. } \\
\text { n.a. }\end{array}$ & $\begin{array}{l}\text { n.a. } \\
\text { n.a. }\end{array}$ & $\begin{array}{l}56-113 \\
5.6-8.1\end{array}$ & Sánchez-Nogué et al., 2012 \\
\hline S. senegalensis & Juveniles & Field: Ebre Delta & $\begin{array}{l}\text { Liver } \\
\text { Gills }\end{array}$ & $\begin{array}{c}0.3-1 \\
\text { n.a. }\end{array}$ & $\begin{array}{c}298-431 \\
74-102\end{array}$ & $\begin{array}{l}\text { n.a. } \\
\text { n.a. }\end{array}$ & $\begin{array}{l}\text { n.a. } \\
\text { n.a. }\end{array}$ & $\begin{array}{l}\text { n.a. } \\
\text { n.a. }\end{array}$ & $\begin{array}{l}36-65 \\
8.6-11\end{array}$ & \\
\hline S. solea & Adults & $\begin{array}{l}\text { Field: NW Mediterranean } \\
\text { Sea }\end{array}$ & $\begin{array}{l}\text { Liver } \\
\text { Gills }\end{array}$ & $\begin{array}{l}0.8-2.6 \\
0.1-0.2\end{array}$ & $\begin{array}{c}235-510 \\
48-107\end{array}$ & $\begin{array}{c}179-303 \\
14-26\end{array}$ & $\begin{array}{l}64-133 \\
96-119\end{array}$ & $\begin{array}{c}13-22 \\
48-115\end{array}$ & $\begin{array}{l}83-121 \\
5.2-7.0\end{array}$ & Present study \\
\hline S. senegalensis & Adults & $\begin{array}{l}\text { Field: NW Mediterranean } \\
\text { Sea }\end{array}$ & $\begin{array}{l}\text { Liver } \\
\text { Gills }\end{array}$ & $\begin{array}{c}0.5-1.4 \\
<0.1\end{array}$ & $\begin{array}{c}324-328 \\
50-63\end{array}$ & $\begin{array}{c}206-275 \\
9-19\end{array}$ & $\begin{array}{c}101 \\
88-106\end{array}$ & $\begin{array}{l}10-17 \\
46-48\end{array}$ & $\begin{array}{c}45-59 \\
8.0-8.3\end{array}$ & Present study \\
\hline
\end{tabular}




\section{Figure legends.}

Figure 1. Liver and gill activities of ethoxyresorufin O-deethylase (EROD), carboxylesterase (CbE) and glutathione $S$-transferase (GST) of $S$. solea (white bars) and S. senegalensis (stripped bars). Data are expressed as mean \pm SEM. In brackets beside each location the number of individual fish analysed. Different letters denote statistical differences after statistical analysis as indicated in Table 2. Significance level set at $\alpha=0.05$.

Figure 2. Antioxidant enzyme activities in liver and gills of S. solea (white bars) and $S$. senegalensis (stripped bars). Different letters: capitals for S. senegalensis and lower case for $S$. solea denote statistical differences after statistical analysis as indicated in Table 2. Data are indicated as mean \pm SEM. Significance level set at $\alpha=0.05$.

Figure 3. (a) Muscular Acetylcholinesterase (AChE) activity and carboxylesterase $(\mathrm{CbE})$ activity in liver (b) and gills (c) after $30 \mathrm{~min}$ in vitro incubations with several concentrations of dichlorvos expressed as percentage of control. * denotes $\mathrm{p}<0.05$ between species at the same concentration of pesticide. Data are expressed as mean \pm $\operatorname{SEM}(n=4)$. 
Fig. 1

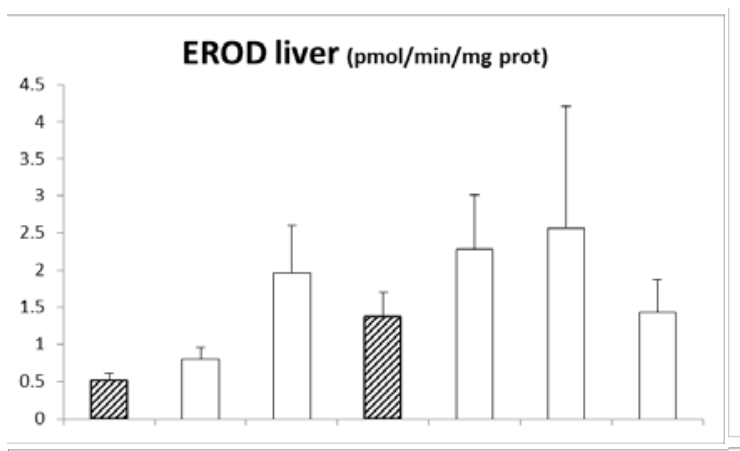

CbE liver (nmol/min/mg prot)
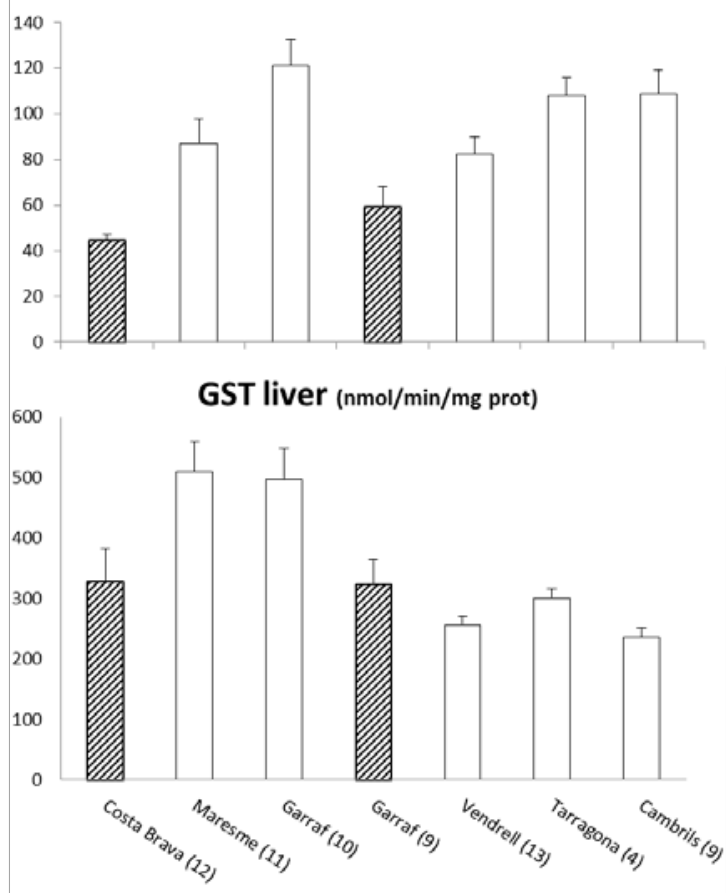

EROD gills (fmol/min/mg prot)

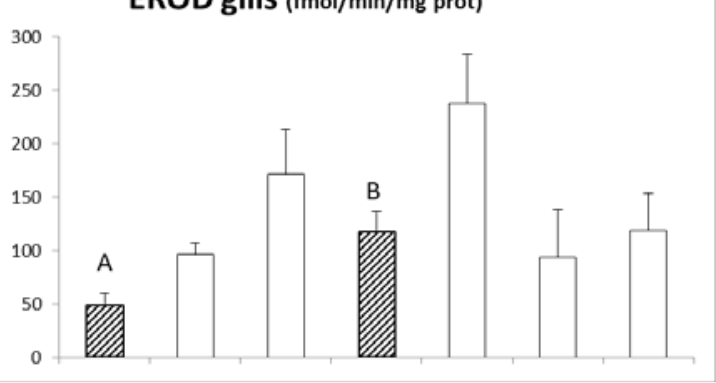

CbE gills (nmol/min/mg prot)

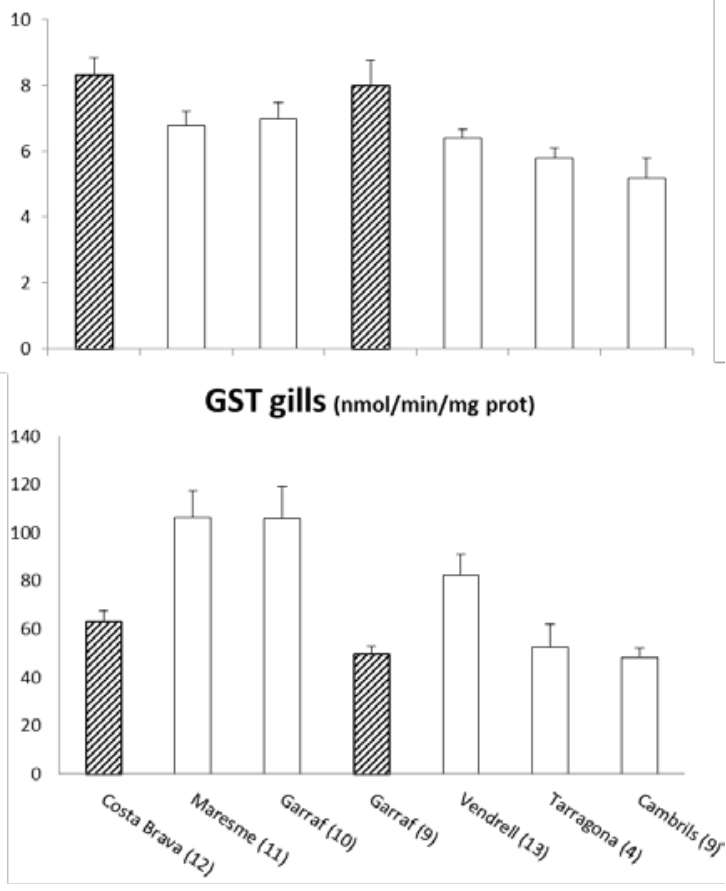


Fig. 2
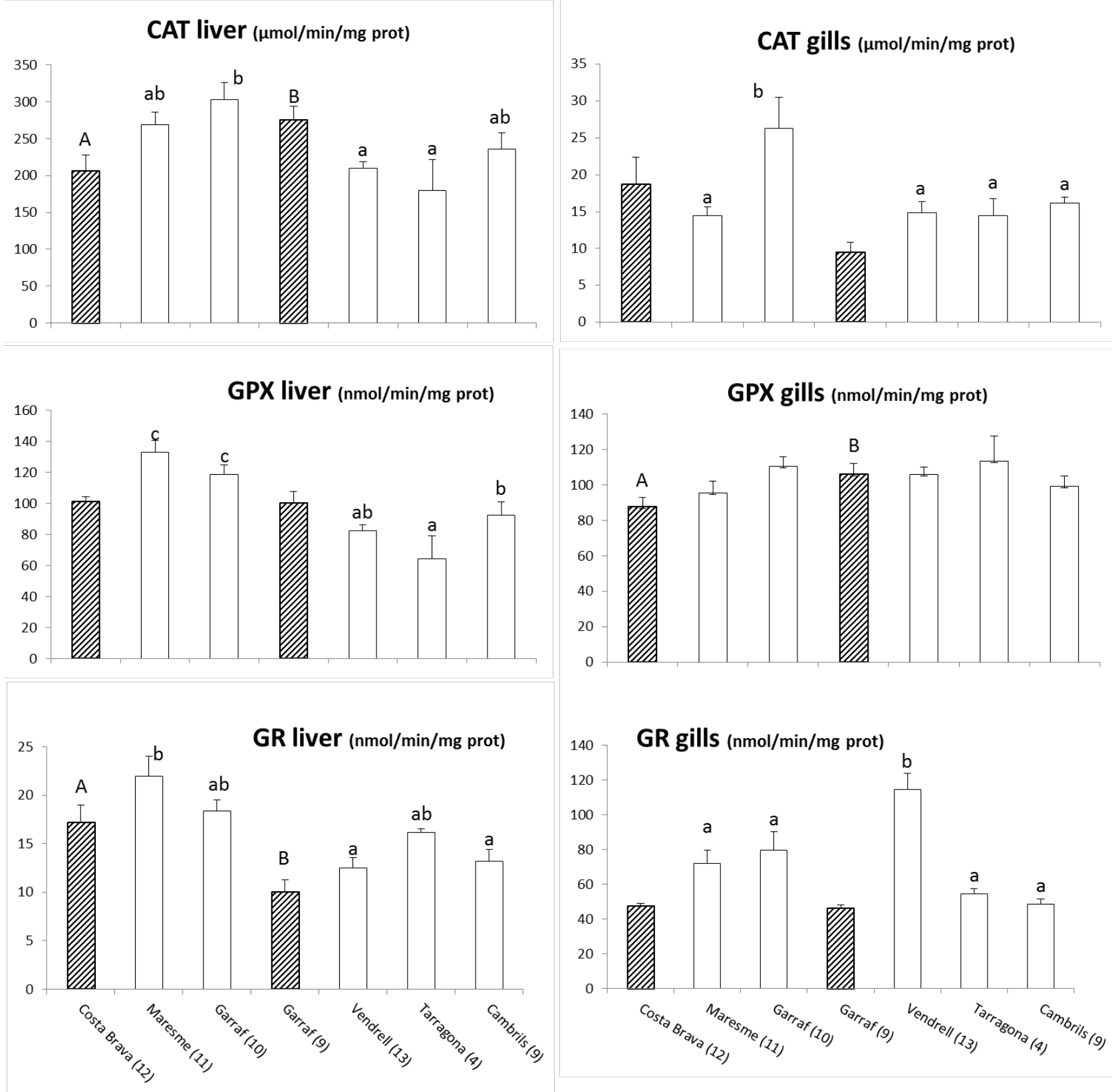

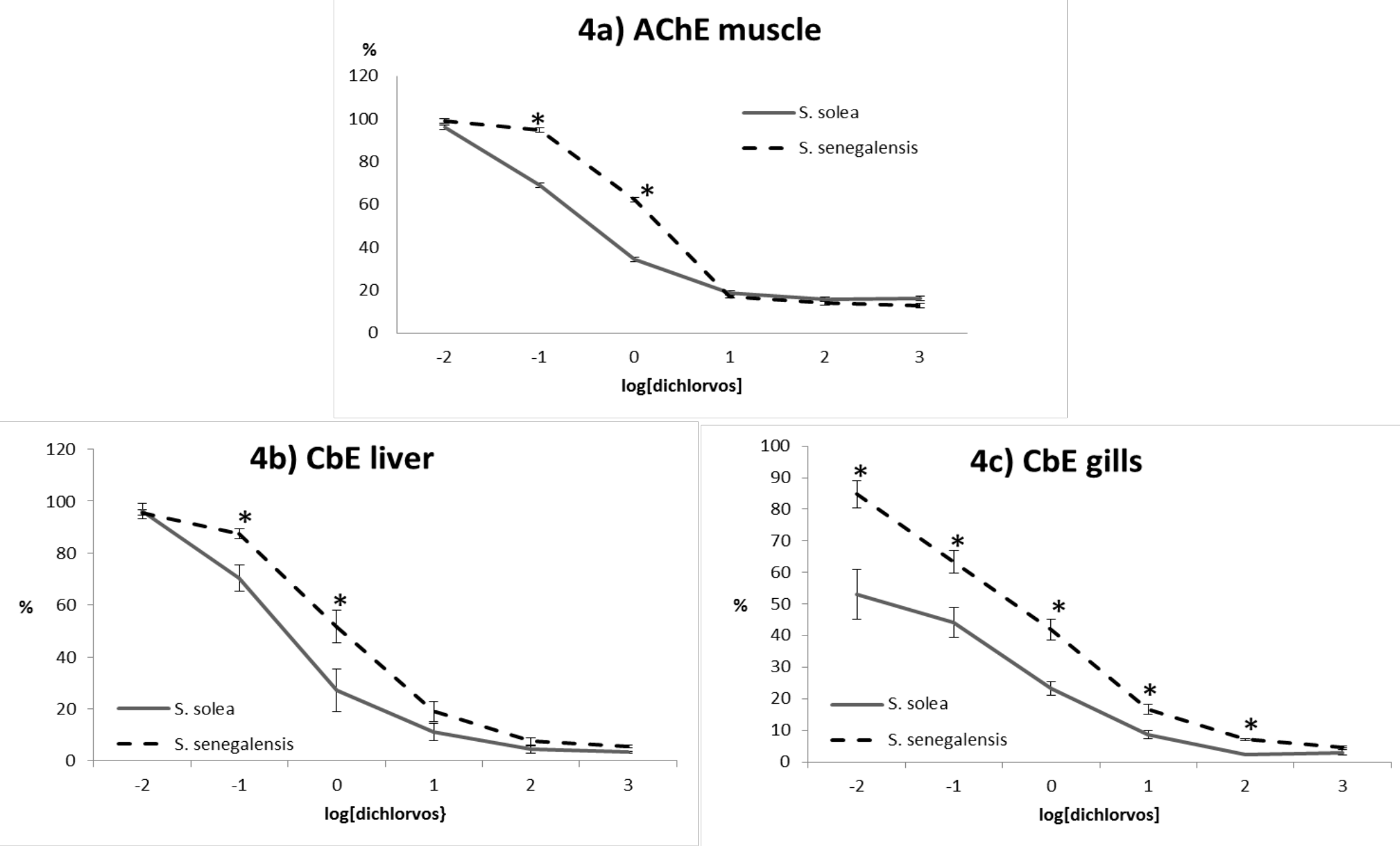

Fig. 3 